\title{
Technical and economic feasibility of gradual concentric chambers reactor for sewage treatment in developing countries
}

\author{
Lourdes Mendoza \\ Laboratory of Microbial Ecology and Technology \\ Faculty of Bioscience Engineering \\ Ghent University \\ Coupure Links 653, B-9000 \\ Ghent, Belgium \\ Marta Carballa \\ Laboratory of Microbial Ecology and Technology \\ Faculty of Bioscience Engineering \\ Ghent University \\ Coupure Links 653, B-9000 \\ Ghent, Belgium \\ Berlian Sitorus \\ Laboratory of Microbial Ecology and Technology \\ Faculty of Bioscience Engineering \\ Ghent University \\ Coupure Links 653, B-9000 \\ Ghent, Belgium \\ Jan Pieters \\ Department of Biosystems Engineering \\ Faculty of Bioscience Engineering \\ Ghent University \\ Coupure Links 653, B-9000 \\ Ghent, Belgium \\ Willy Verstraete* \\ Laboratory of Microbial Ecology and Technology \\ Faculty of Bioscience Engineering \\ Ghent University \\ Coupure Links 653, B-9000 \\ Ghent, Belgium \\ Fax: 32092646248 \\ E-mail: willy.verstraete@ugent.be
}

Financial support: Belgian Technical Cooperation (BTC) and the Xunta de Galicia (Ángeles Alvariño program, AA-065).

Keywords: developing countries, mesophilic, nutrients removal, reactor design, sewage.

\author{
Abbreviations: COD: chemical oxygen demand \\ DO: dissolved oxygen \\ GCC: gradual concentric chambers \\ HRT: hydraulic retention time \\ I.E.: inhabitant equivalent \\ SND: simultaneous nitrification-denitrification process \\ TAN: total ammonia nitrogen \\ TKN: total kjeldahl nitrogen \\ TON: total oxidised nitrogen \\ TSS: total suspended solid \\ UASB: upflow anaerobic sludge bed \\ VFA: volatile fatty acids \\ VSS: volatile suspended solids
}

A major challenge in developing countries concerning domestic wastewaters is to decrease their treatment costs. In the present study, a new cost-effective reactor called gradual concentric chambers (GCC) was

*Corresponding author 
designed and evaluated at lab-scale. The effluent quality of the GCC reactor was compared with that of an upflow anaerobic sludge bed (UASB) reactor. Both reactors showed organic matter removal efficiencies of $90 \%$; however, the elimination of nitrogen was higher in the GCC reactor. The amount of biogas recovered in the GCC and the UASB systems was $50 \%$ and $75 \%$ of the theoretical amount expected, respectively, and both reactors showed a slightly higher methane production when the feed was supplemented with an additive based on vitamins and minerals. Overall, the economical analysis, the simplicity of design and the performance results revealed that the GCC technology can be of particular interest for sewage treatment in developing countries.

Efficient wastewater treatment technology is costly, basically due to energy requirements, i.e. aeration, and chemical needs, bringing about high operational costs. Industrialized high income countries have the means and knowledge to invest in highly sophisticated and efficient wastewater treatment plants. However, developing countries lack capital for investment, technologies adapted to the climate conditions and skilled labour force to treat sewage. Aiyuk et al. (2004) discussed the need to develop reliable technologies to treat domestic wastewater in the developing world, which are mostly tropical regions. ElGohary and Nasr (1999) also pointed out that in developing countries, where capital and skills are not readily available, solutions to wastewater treatment should preferably be lowtechnology oriented.

The efforts to get effective designs in terms of simple and non-sophisticated equipment, low capital investment costs and low operating and maintenance costs have resulted into the so-called low investment sewage treatment (LIST) concept. The overall capex and opex costs should not exceed $30 €$ per inhabitant equivalent (I.E.) per year (Sandino, 2007). The present work evaluates a novel Gradual Concentric Chambers (GCC) reactor, which combines anaerobic and aerobic treatment by using a simple assemblage of inexpensive vessels. One of the most attractive points is that no heavy material carrying walls are needed, except for the outer compartment. The performance of the GCC reactor treating medium-strength sewage has been compared with a well known and efficient technology, the Upflow Anaerobic Sludge Bed (UASB) reactor, in terms of organic matter and nutrient removal and biogas production. An approximate cost analysis of GCC reactor is also presented in order to evaluate its application at a decentralized level in municipalities of low income countries.

\section{MATERIALS AND METHODS}

\section{Experimental set-up}

The lab-scale GCC reactor set-up consisted of 3 containers, arranged up-side right and down to create the different compartments (Table 1, Figure 1). The influent was pumped to the bottom of the anaerobic compartment. The concentric distribution of the containers allowed the effluent of the anaerobic compartment to enter the outer aerobic compartment. Deflectors were used to increase the contact between the sludge and the mixed liquor as well as to decrease the sludge wash out. The biogas was collected by volume displacement in a graduated glass column immersed in acidified water $(\mathrm{pH}<4,2 \mathrm{~N} \mathrm{HCl})$ to prevent $\mathrm{CO}_{2}$ dissolving. A 51 UASB reactor, as described by Kalogo et al. (2001), was used as reference.

\section{Influent}

The feeding of both reactors consisted of raw wastewater (Ossemeersen Waste Water Treatment Plant, Ghent, Belgium) containing a total chemical oxygen demand (CODt) concentration of $190 \pm 95 \mathrm{mg} \mathrm{l}^{-1}$ (Table 2). In order to obtain a medium-strength sewage (around $600 \mathrm{mg}$ COD $\mathrm{I}^{-1}$ ), the raw wastewater was supplemented with sodium acetate during the experimental period.

\section{GCC and UASB reactor start-up and performance}

The anaerobic compartment of the GCC and the UASB reactor were inoculated with 1.61 and 1.41 of anaerobic sludge $\left(\mathrm{VSS}=17 \mathrm{~g} \mathrm{l}^{-1}\right.$ ), respectively, coming from an industrial mesophilic anaerobic digester of a potato processing treatment plant (Primeur, Waregem, Belgium).

The reactors were operated at $33 \pm 2^{\circ} \mathrm{C}$ and two periods can be differentiated: the start-up and the experimental phase. During the start-up (2 months), the most suitable operational conditions for the experimental phase were investigated (Barber and Stuckey, 1999). Increasing organic loading rates $(\mathrm{Bv})$ of $1.8-6 \mathrm{~g} \mathrm{COD}^{-1} \mathrm{~d}^{-1}$ and $1.5-3.4 \mathrm{~g}$ COD $1^{-1} \mathrm{~d}^{-1}$ were applied in the UASB and the GCC reactor, respectively, in order to determine the maximum capacity of each system (data not shown). From the results obtained, four phases were selected for the experimental period, in terms of $\mathrm{Bv}$, hydraulic retention time (HRT) and the temporary addition of an additive to optimize methanogenesis (Table 3 ). The additive contained all the necessary vitamins and minerals for a complete and wellbalance nutritive balance and it was supplied at a rate of 20 $\mathrm{mg}^{-1}$ reactor $\mathrm{d}^{-1}$. A gravel bed for solids and biomass settling and aeration were included in the aerobic compartment. For aeration, a low energy demand internal filter pump (Eheim aquaball, EH-2208020, Germany), whose function was to rotate concentrically the upper water layers, was used. No sludge was harvested during the reactors performance (solid retention time $=\infty$ ).

\section{Analytical methods}

CODt and soluble COD (CODs), total suspended solids (TSS), volatile suspended solids (VSS), total Kjeldahl Nitrogen (TKN), total ammonia nitrogen (TAN), total oxidised nitrogen (TON) and $\mathrm{pH}$ analysis were routinely 


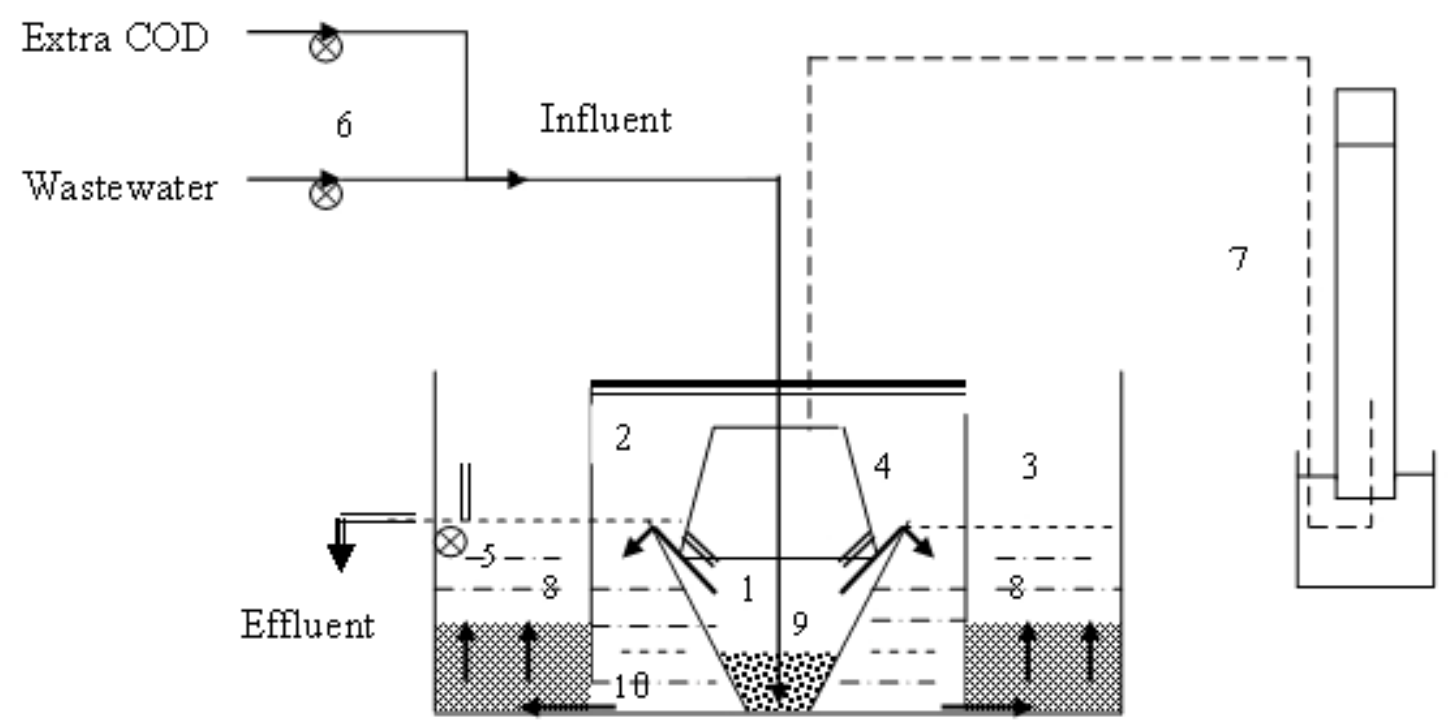

Figure 1. Layout of the lab-scale GCC reactor. 1. Anaerobic compartment. 2. Headspace. 3. Aerobic compartment. 4. Gas deflector. 5. Water cycling pump. 6. Influent pumps. 7. Biogas collection system. 8. Gravel bed. 9. Sludge bed. 10. Anaerobic effluent. ( $\rightarrow$ ) Liquid flow. $(-\rightarrow)$ Gas flow.

performed according to Standard Methods (APHA, 2000). Volatile fatty acids content (VFA) was analysed using a gas chromatograph GC 8000 Top Series (CE Instruments, Italy) equipped with an autosampler AS 800 (CE Instruments), a capillary column Phase $\mathrm{EC}^{\mathrm{TM}}-1000\left(110-165^{\circ} \mathrm{C}\right)$, a flame ionization detector (FID, $200^{\circ} \mathrm{C}$ ) and with $\mathrm{N}_{2}$ as carrier gas. The biogas composition $\left(\mathrm{CH}_{4}\right.$ and $\left.\mathrm{CO}_{2}\right)$ was analysed using a gas chromatograph GC-14B (Shimadzu, Japan) equipped with a custom packed column Alltech PC-5000 $\left(45-80^{\circ} \mathrm{C}\right)$, a thermal conductivity detector $\left(\mathrm{TCD}, 200^{\circ} \mathrm{C}\right)$ and with helium as carrier gas.

\section{Economic evaluation of GCC reactor}

An estimate was made for the construction costs of a pilot $\left(10 \mathrm{~m}^{3}\right)$ and an industrial scale $\left(100 \mathrm{~m}^{3}\right)$ GCC reactor treating sewage at the average production rate typical for rural areas in developing countries of 801 I.E. $^{-1} \mathrm{~d}^{-1}$ (Schellinkhout and Collazos, 1992; Van Haandel and Lettinga, 1994). A volume of $10 \%$ for the anaerobic compartment of the pilot and industrial scale GCC reactor was selected. An average HRT of $5 \mathrm{hrs}$ (based on the anaerobic compartment) was considered, which provides flow rates of $5 \mathrm{~m}^{3} \mathrm{~d}^{-1}$ (serving about 63 I.E.) for the pilot reactor and $50 \mathrm{~m}^{3} \mathrm{~d}^{-1}$ (serving about 625 I.E.) for the industrial one. It is expected that the costs of the materials contribute significantly to the overall costs. Therefore, the most and the least expensive materials were considered for the inner compartments, i.e. stainless steel and high density polyethylene. Concrete and PVC (not specified) were selected for the outer compartment and pipes, respectively.

Some authors have reported the use of flat thermal solar collectors as an alternative energy to heat anaerobic reactors (Dirk et al. 1999; El-Mashad et al. 2004). The feasibility of a solar-heated GCC reactor was evaluated in the present study with reference values related to a low income country, i.e. Ecuador. The flat collectors are supposed to cover $80 \%$ of the heating demand, working at $40 \%$ efficiency (Thür et al. 2006). In our design, only the anaerobic compartment is heated and it was estimated that $5 \mathrm{hrs}$ of daily light peak are required. Thus, to raise the wastewater temperature from $16^{\circ} \mathrm{C}$ (average for Andean regions) to $35^{\circ} \mathrm{C}$, the pilot reactor requires c.a. $22 \mathrm{kWh} \mathrm{d}$ (29030 MJ y ${ }^{-1}$ ), equivalent to $18 \mathrm{~m}^{2}$ of flat plate collectors (9 plates, $2 \mathrm{~m}^{2}$ per plate, $0.5 \mathrm{kWh} \mathrm{h}^{-1}$ per plate). Each plate is assumed to cost 180 USD (EEQ, 2007). The industrial reactor would require 10 times more energy, i.e. $220 \mathrm{kWh}$ $\mathrm{d}^{-1}$ or 290, $300 \mathrm{MJ} \mathrm{y}^{-1}$ (Goswami et al. 1999), corresponding to c.a. $176 \mathrm{~m}^{2}$ of flat plate collectors. Heat losses were not taken into account in the aforementioned energy calculations.

\section{RESULTS}

\section{CODt removal}

A stable feeding solution based on sodium acetate strengthened wastewater was used during the experimental period (Table 2).

Figure 2 shows the variation of the CODt concentrations in the influent and effluent of the GCC and UASB reactors, respectively. The average CODt content of the GCC reactor feeding was $578 \pm 53 \mathrm{mg} \mathrm{l}^{-1}$. Low CODt concentrations were detected in the effluent, ranging from 37 to $89 \mathrm{mg} \mathrm{l}^{-1}$ (59 $\pm 13 \mathrm{mg} \mathrm{l}^{-1}$, average concentration). This was also consistent with the low VFA concentrations obtained; only acetate was commonly detected at average concentrations of $3 \mathrm{mg} \mathrm{l}^{-1}$. The CODt removal efficiency in the GCC 

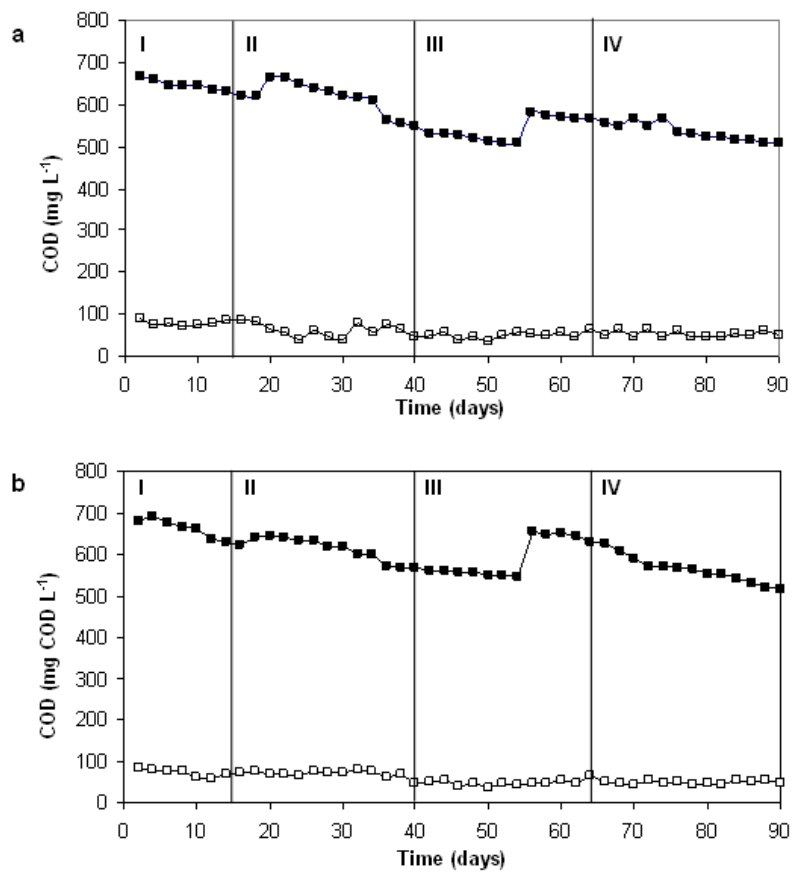

Figure 2. Variation of the CODt in the influent (a) and effluent ( $\square$ ) of the GCC (a) and UASB (b) reactors. See Table 3 for the characteristics of each operational phase.

reactor was $88 \pm 1 \%$ in phase I, $90 \pm 3 \%$ in phase II, $91 \pm$ $1 \%$ in phase III and $90 \pm 1 \%$ in phase IV. It resulted in an average removal efficiency of $90 \pm 2 \%$ for the whole period $\left(\mathrm{Bv}=1.4-2.2 \mathrm{~g} \mathrm{COD} \mathrm{l}^{-1} \mathrm{~d}^{-1}\right)$. It was also noticed that the additive used did not affect the GCC reactor performance in terms of COD elimination.

The CODt influent concentrations of the UASB reactor ranged from 516 to $691 \mathrm{mg} \mathrm{l}^{-1}$, resulting in an average CODt of $600 \pm 48 \mathrm{mg} \mathrm{l}^{-1}$, while the levels in the effluent averaged $59 \pm 13 \mathrm{mg} \mathrm{l}^{-1}$. As a result, a CODt removal efficiency of $90 \pm 2 \%$ was attained. Hence, this result was similar to that obtained in the GCC reactor.

Total kjeldahl nitrogen (TKN), total ammonia nitrogen (TAN) and total oxidized nitrogen (TON)

The average TKN value of the feeding was $51 \pm 4 \mathrm{mg} \mathrm{l}^{-1}$ (Table 2). The GCC and the UASB reactor showed an average TKN removal efficiency of $57 \pm 7 \%$ and $17 \pm 9 \%$, respectively (Table 4). In the GCC reactor, the TKN removal remained constant along the four phases, while the UASB reactor showed increased values. The TAN influent concentrations averaged $37 \pm 6 \mathrm{mg} \mathrm{l}^{-1}$ (Table 2). Lower TAN concentrations were obtained in the effluent of the GCC reactor $\left(14 \pm 4 \mathrm{mg} \mathrm{l}^{-1}\right)$ in comparison with those of the UASB reactor $\left(40 \pm 6 \mathrm{mg} \mathrm{l}^{-1}\right)$. Both reactors showed negligible nitrite and nitrate levels in the effluent $\left(<2 \mathrm{mg} \mathrm{l}^{-}\right.$ ${ }^{1}$ ), which indicates that the elimination of TKN and TAN in the GCC reactor did not result in the $\mathrm{NO}_{2-}$ and $\mathrm{NO}_{3}$ production.

\section{Solids analysis}

The GCC reactor promoted higher TSS and VSS removal, $40 \pm 9 \%$ and $86 \pm 2 \%$, respectively, than the UASB reactor, $25 \pm 6 \%$ and $41 \pm 15 \%$ (data not shown). The reason for this higher solids removal in the GCC reactor could be the deposition of particles in the gravel bed. Indeed the dynamic conditions in the sludge-containing compartment are much lower in the GCC relative to the UASB reactor. Although low solids removal is common in UASB operation, elimination can be improved by optimizing the settling conditions (Mahmoud et al. 2003). No significant biomass growth was observed in any reactor during the experimental period.

\section{Biogas and methane recovery}

Figure 3 shows the biogas and methane recovery in the GCC and UASB reactors, respectively, during the experimental period. Biogas and methane production are expressed as volume produced per amount of COD removed. Recoveries refer to the total biogas (or methane) produced in relation to the expected theoretical volumes, 0.5 and 0.351 of biogas and methane, respectively, per $g$ of COD removed (Tchobanoglous et al. 2003).

The biogas recovery was similar in both reactors, varying from 30 to $60 \%$; however the methane recovery in the GCC reactor $(18-53 \%)$ was lower than that of the UASB reactor (28-75\%), which could be explained by $\mathrm{CH}_{4}$ losses in the anaerobic effluent getting into the outer aerobic compartment.

\section{Microbial analysis}

A semi-quantitative fecal coliform analysis of raw wastewater, using Mc Conckey agar as culture media, showed values of $10^{8}-10^{10} \mathrm{CFU} 1^{-1}$ (Table 2). The GCC reactor effluent showed values between $2 \cdot 10^{7}$ and $4 \cdot 10^{7}$ CFU ${ }^{-1}$, thus indicating a decrease of the fecal bacteria of 1-3 log. Although these concentrations are lower than those reported for UASB reactor effluents (Van Haandel and Lettinga, 1994), i.e. 1000 E. coli/100 ml, they still exceed the discharge limit proposed by EPA $(2004)\left(<4.10^{2} \mathrm{CFU}\right.$ $\left.100 \mathrm{ml}^{-1}\right)$.

\section{GCC economics}

Table 5 presents the estimated solar flat-plate collectors installation costs. The installation of the proposed flat-plate collectors was priced at 208 and $163 \mathrm{USD} \mathrm{m}^{-2}$ for the pilot and the industrial GCC reactors design, respectively. Considering the local price for electricity $0.089 \mathrm{USD} \mathrm{kWh}^{-1}$ (without taxes) (EEQ, 2007), the total annual energy costs using a conventional electric resistance equipment would amount to about 894 and $8,932 \mathrm{USD} \mathrm{y}^{-1}$, for the pilot and full scale system, respectively.

Table 6 shows the total estimated costs of the reactors. The item salaries refers to the payment of extra hours required 

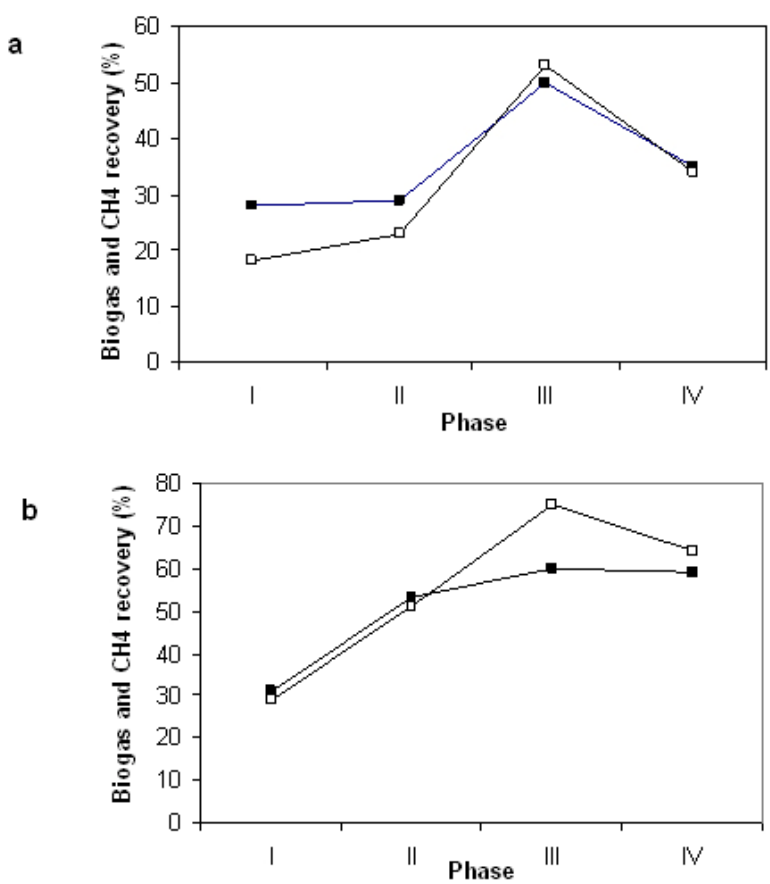

Figure 3. Biogas ( $\square$ ) and methane ( $\square$ ) recovery for the GCC (a) and the UASB (b) reactors.

in case of reactor failure since its control and operation can be performed by the own personnel of the municipal wastewater treatment facilities.

Table 7 shows the annual costs per I.E. and per $\mathrm{m}^{3}$ of wastewater, respectively. Option 1 at pilot-scale, using plastic material and solar heating, resulted in a total construction cost of 3.9 USD I.E. $^{-1} \mathrm{y}^{-1}$, operational costs of 14.8 USD I.E. ${ }^{-1} \mathrm{y}^{-1}$ and 0.6 USD m$^{-3}$ wastewater. From an energetic point of view, $4.7 \mathrm{kWh}$ of electricity per $\mathrm{m}^{3}$ wastewater were needed. Applying the same conditions to the full-scale system, the results obtained were: total construction costs of 3.0 USD I.E. ${ }^{-1} \mathrm{y}^{-1}$, operational expenditures of 5 USD I.E. $^{-1} \mathrm{y}^{-1}$ and 0.3 USD m ${ }^{-3}$ wastewater. In terms of energy, $1.7 \mathrm{kWh}$ of electricity per $\mathrm{m}^{3}$ wastewater were needed.

\section{DISCUSSION}

In this work, a GCC reactor was evaluated technically and economically for sewage treatment in developing countries. A high CODt removal efficiency of $90 \%$ can be achieved in the GCC reactor at $33^{\circ} \mathrm{C}$ when a medium strength wastewater was treated at $\mathrm{Bv}$ of 2.0-2.2 $\mathrm{g} \mathrm{COD} \mathrm{l}^{-1} \mathrm{~d}^{-1}$ and HRT of 42-45 hrs. The removal of TKN and TAN appears to be also effective, 57 and $61 \%$, respectively, without increasing nitrite and nitrate concentrations in the effluent. Partial simultaneous nitrification-denitrification process (SND) could occur in the outer compartment (oxic conditions), where increasing dissolved oxygen (DO) concentrations from the lower water layers (gravel bed) to the upper water layers are present (Chelme et al. 2008). Chiu et al. (2007) studied the influence of COD/ $\mathrm{NH}_{4}{ }^{+}$ratios on SND process treating domestic wastewater and they stated that a minimum value of 6 for this ratio as well as low DO levels (0.3-0.8 $\left.\mathrm{mg}^{-1}\right)$ are needed for a partial SND process. Both requirements are likely to happen in the GCC reactor.

Besides, the GCC effluent was odorless and low in turbidity, and a partial hygienisation in terms of fecal bacteria was achieved.

The biogas production in the GCC and UASB systems accounted for 50 and $75 \%$ of the theoretical expected value, respectively. The anaerobic treatment of low and medium strength wastewaters usually leads to a loss of more than $50 \%$ of biogas in the water phase (Lettinga et al. 1993). In both reactors, the higher biogas and methane recoveries were obtained in phase III. This effect is possibly related to the input of the additive, which optimizes the nutritive balance between the different bacterial groups within the microbial consortium, and thus increasing the methanogenesis.

Table 6 reveals that the type of material (option 1 vs. option 2 ) and energy are the main factors affecting the construction and operational costs of the GCC system. Although the installation costs of the proposed flat-plate collectors are lower than those reported by Dirk et al. (1999), they double in the best case the reactor construction costs. However, the operational expenditures are lower, saving up to $50 \%$ of the electrical needs.

Table 8 shows the costs of different wastewater treatment technologies commonly applied in Latin America. Schellinkhout and Collazos (1992) reported 1,715 USD for the construction of an UASB reactor, serving 96 I.E. (78.4 L sewage I.E. $^{-1} \mathrm{~d}^{-1}$ ) and yielding a total COD removal efficiency of $75 \%$. It resulted in an estimated construction investment of $17 \mathrm{USD} \mathrm{I.E.}^{-1}$ and $0.07 \mathrm{USD} \mathrm{m}^{-3}$ of wastewater. However, this budget did not take into consideration heating costs (as it was supposed to work at ambient temperature) and overall prices for energy consumption were not reported. In this study, the opex costs obtained for the industrial scale GCC reactor containing polyethylene vessels were 5 USD I.E. ${ }^{-1} \mathrm{y}^{-1}$ with solar collectors and 16 USD I.E. $^{-1} \mathrm{y}^{-1}$ without solar collectors. Without energy requirements (reactors working at ambient temperature), these costs would decrease to 2 USD I.E. ${ }^{-1} \mathrm{y}^{-1}$ and 0.1 USD m ${ }^{-3}$ of wastewater, accordingly. It should be also taken into account that the treatment of a medium strength wastewater (c.a. $500 \mathrm{mg} \mathrm{COD} \mathrm{l}^{-1}$ ) at industrial scale (c.a. $50 \mathrm{~m}^{3} \mathrm{~d}^{-1}$ ) will generate about $6 \mathrm{~m}^{3} \mathrm{~d}^{-1}$ of methane (c.a. $25 \mathrm{kWh} \mathrm{d}^{-1}$ ), which could cover the remaining $20 \%$ of energy not provided by the collectors, and thus decreasing the operation costs of the solar-heated reactor. 
Comparing with a European country, such as Belgium (50 $\mathrm{m}^{3}$ I.E. $^{-1} \mathrm{y}^{-1}$, with an average treatment costs of $30 €$ I.E. $^{-1} \mathrm{y}^{-}$ $\left.{ }^{1}\right)$, the costs of wastewater treatment in Europe $\left(0.6 € \mathrm{~m}^{-3}\right.$ wastewater) double those calculated in this study at large scale (0.3 USD m${ }^{-3}$ wastewater), but they are of the same order at small scale (0.6 USD m ${ }^{-3}$ wastewater).

Therefore, the simplicity of design, the performance results and the economical analysis indicate that the GCC reactor can be a competitive technology for sewage treatment in developing countries ( $<1 \mathrm{USD} \mathrm{m}^{-3}$ wastewater).

\section{ACKNOWLEDGMENTS}

The authors thank to: Michael De Cooman and Bert Vermeire, from the Faculty of Bioscience Engineering, Ghent University; and Dr. Adrianus Van Haandel, University of Campina Grande, Brasil.

\section{REFERENCES}

AIYUK, Sunny E.; AMOAKO, Joyce; RASKIN, Lutgarde.; VAN HAANDEL, Adrianus and VERSTRAETE, Willy. Removal of carbon and nutrients from domestic wastewater using a low investment, integrated treatment concept. Water Research, July 2004, vol. 38 , no. 13, p. 3031-3042.

APHA. Standard Methods for the examination of Water and Wastewater. $20^{\text {th }}$ ed, American Public Health Association, Washington, D.C., 2000. ISBN 0875532357.

ARIAS, M.E. Feasibility of using constructed treatment wetlands for municipal wastewater treatment in the Bogotá Savannah, Colombia. Journal of Undergraduate Research, September-October 2006, vol. 8, no. 1.

BARBER, William and STUCKEY, David C. The use of the anaerobic baffled reactor (ABR) for wastewater treatment: A review. Water Research, May 1999, vol. 33, no. 7 , p. 1559-1578.

CHELME, Susana; FONSECA, Pamela; MERCADO, Rodrigo; ALARCÓN, Nelson and SÁNCHEZ, Omar. Macromolecular composition and anaerobic degradation of the sludge produced in a sequencing batch reactor. Electronic Journal of Biotechnology, July 2008, vol. 11, no. 3, p. 1-7.

CHIU, Ying-Chih; LEE, Li-Ling; CHANG, Cheng-Nan and CHAO, Allen C. Control of carbon and ammonium ratio for simultaneous nitrification and denitrification in a sequencing batch bioreactor. International Biodeterioration \& Biodegradataion, January 2007, vol. 59, no. 1, p. 1-7.

DIRK, H.; NESKAKIS, A. and XANTHOULIS, D. Wastewater recycling of olive mills in Mediterranean countries (WAWAROMED). Demonstration and sustainable reuse of residuals, European Communities, 1999, Project Reference: ICA3-CT-1999-00011.
EMPRESA ELÉCTRICA DE QUITO (EEQ) (Quito Electrical Enterprise). Pliego Tarifario. December 2007, Quito Metropolitan Municipality. Dirección Metropolitana de Medio Ambiente, Ecuador.

EL-GOHARY, Fatma A. and NASR, Fayza A. Costeffective pre-treatment of wastewater. Water Science and Technology, May 1999, vol. 39, no. 5, p. 97-103.

EL-MASHAD, Hamed M.; VAN LOON, Wilko K.P.; ZEEMAN, Grietje; BOT, Gerard P.A. and LETTINGA, Gatze. Design of a solar thermophilic reactor for small farms. Biosystems Engineering, March 2004, vol. 87, no. 3, p. 345-353.

EPA. Environmental Protection Agency, 2004. Available from Internet: http://www.epa.state.il.us/publicnotices/2004/lincoln-trails-mhp/draft-permit.pdf. 6 p.

GOSWAMI, Y.; KREITH, F. and KREIDER, J.F. Principles of solar engineering. $2^{\text {nd }}$ ed, Taylor \& Francis Publishers, 1999, USA, 545 p. ISBN 1-56032-714-6.

KALOGO, Y.; MBOUCHE, J.H. and VERSTRAETE, W. Physical and biological performance of self-inoculated UASB reactor treating raw domestic sewage. Journal of Environmental Engineering ASCE, February 2001, vol. 127, no. 2, p. 179-183.

LETTINGA, G.; DEMAN, A.; VANDERLAST, A.R.M.; WIEGANT, W.; VANKNIPPENBERG, K.; FRIJNS, J. and VANBUUREN, J.C.L. Anaerobic treatment of domestic sewage and wastewater. Water Science and Technology, September 1993, vol. 27, no. 9, p. 67-73.

MAHMOUD, Nidal; ZEEMAN, Grietje; GIJZEN, Huub and LETTINGA, Gatze. Solids removal in upflow anaerobic reactors: A review. Bioresource Technology, October 2003, vol. 90, no. 1, p. 1-9.

SANDINO, J. Selecting appropriate wastewater treatment technologies for large urban applications in developing countries. Water 21, February 2007, vol. 1, no. 1, p. 42-44.

SCHELLINKHOUT, A. and COLLAZOS, C.J. Full-scale application of the UASB technology for sewage treatment. Water Science and Technology, July 1992, vol. 25, no. 7, p. 159-166.

TCHOBANOGLOUS, G.; BURTON, F.L and STENSEL, H.D. Wastewater engineering. International edition: treatment and reuse. $4^{\text {th }}$ ed, McGraw-Hill 2003, Inc., New York, p. 986-996. ISBN 0071122504.

THÜR, Alexander; FURBO, Simon and SHAH, Louise Jivan. Energy saving for solar heating systems. Solar Energy, November 2006, vol. 80, no. 11, p. 1463-1474.

VAN HAANDEL, A. and LETTINGA, G. Anaerobic Sewage Treatment: A Practical Guide for Regions with a 
Technical and economic feasibility of gradual concentric chambers reactor for sewage treatment in developing countries

Hot Climate. John Wiley \& Sons Publishers; England, 1994, p. 1-32, 91-120. ISBN 0471951218. 


\section{APPENDIX \\ TABLES}

Table 1. Dimensions of the lab scale GCC reactor.

\begin{tabular}{|l|c|c|c|c|}
\hline \multirow{2}{*}{} & \multicolumn{3}{|c|}{ Compartment } \\
\cline { 2 - 5 } & Inner anaerobic & Outer Anaerobic* & Aerobic & Gas deflector \\
\hline Diameter (mm) & $170-260$ & 300 & - & $125-200$ \\
\hline Height (mm) & 205 & 165 & 400 & 185 \\
\hline Length (mm) & - & - & 500 & - \\
\hline Width (mm) & - & - & 400 & - \\
\hline Volume (l) & 7.5 & 11.6 & 33.2 & 5.0 \\
\hline
\end{tabular}

*Volume of anaerobic effluent in the outer compartment is $6.3 \mathrm{I}$ (headspace: $5.3 \mathrm{I}$ ).

Table 2. Characteristics of the raw wastewater used to prepare the reactors feeding.

\begin{tabular}{|c|c|c|}
\hline Parameter & Unit & Value \\
\hline $\mathrm{pH}$ & & $7.6 \pm 0.2^{\star}(n=90)$ \\
\hline $\mathrm{COD}_{\mathrm{t}}$ & $\mathrm{mg} \mathrm{l}^{-1}$ & $589 \pm 50^{\star}(n=45)$ \\
\hline $\mathrm{COD}_{\mathrm{s}}$ & $\mathrm{mg} \mathrm{I}^{-1}$ & $313 \pm 25^{\star}(n=20)$ \\
\hline $\mathrm{NH}_{4}^{+}-\mathrm{N}$ & $\mathrm{mg} \mathrm{l}^{-1}$ & $37 \pm 6(n=45)$ \\
\hline TON & $\mathrm{mg} \mathrm{l}^{-1}$ & $0(n=45)$ \\
\hline TKN & $\mathrm{mg} \mathrm{l}^{-1}$ & $51 \pm 4(n=45)$ \\
\hline TSS & $\mathrm{mg} \mathrm{l}^{-1}$ & $213 \pm 35(n=20)$ \\
\hline VSS & $\mathrm{mg} \mathrm{I}^{-1}$ & $128 \pm 26(n=20)$ \\
\hline $\mathrm{P}-\mathrm{PO}_{4}{ }^{3-}$ & $\mathrm{mg} \mathrm{l}^{-1}$ & $5 \pm 2(n=20)$ \\
\hline Fecal coliforms & CFU I ${ }^{-1}$ & $10^{8}-10^{10}(n=20)$ \\
\hline
\end{tabular}

*Value after strengthening with sodium acetate. 
Table 3. Values of the parameters used in the experimental period.

\begin{tabular}{|c|c|c|c|c|}
\hline & Phase I & Phase II & Phase III & Phase IV \\
\hline & Low rate & High rate & High rate + additive & High rate as in phase II \\
\hline Duration (d) & Days 1 - 16 & Days 17 - 40 & Days 41 - 64 & Days 65 - 90 \\
\hline \multicolumn{5}{|c|}{$\operatorname{Bv}\left(g \operatorname{COD} I^{-1} d^{-1}\right)$} \\
\hline $\mathrm{GCC}^{\mathrm{a}}$ & $1.4-1.6$ & $2.0-2.2$ & $2.0-2.2$ & $2.0-2.2$ \\
\hline UASB & $1.4-1.5$ & $2.0-2.5$ & $2.0-2.2$ & $2.0-2.2$ \\
\hline \multicolumn{5}{|l|}{ HRT (h) } \\
\hline GCC & $\begin{array}{c}61-65^{b} \\
9.7-10.4^{c}\end{array}$ & $\begin{array}{l}42-45^{b} \\
6.2-6.4^{c}\end{array}$ & $\begin{array}{l}42-45^{b} \\
6.2-6.4^{c}\end{array}$ & $\begin{array}{l}42-45^{b} \\
6.2-6.4^{c}\end{array}$ \\
\hline UASB & $10.5-11.0$ & $6.5-7.0$ & $6.5-7.0$ & $6.5-7.0$ \\
\hline Additive & No & No & Yes & No \\
\hline
\end{tabular}

${ }^{\mathrm{a}} \mathrm{Bv}$ value calculated based on anaerobic compartment volume (7.5 I).

${ }^{\mathrm{b}} \mathrm{HRT}$ based on total reactor volume (47 I).

${ }^{\mathrm{c}} \mathrm{HRT}$ based on the anaerobic compartment volume.

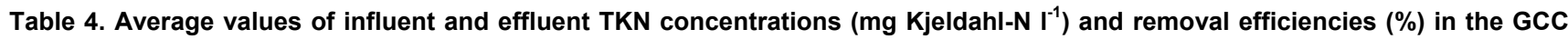
and UASB reactors.

\begin{tabular}{|c|c|c|c|c|}
\hline & Phase & Influent & Effluent & Removal efficiency \\
\hline \multirow{5}{*}{ GCC } & $I(n=8)$ & $45 \pm 2$ & $21 \pm 3$ & $55 \pm 6$ \\
\hline & $\|(n=12)$ & $51 \pm 3$ & $22 \pm 4$ & $57 \pm 9$ \\
\hline & III $(n=12)$ & $55 \pm 2$ & $24 \pm 2$ & $57 \pm 4$ \\
\hline & $\mathrm{IV}(\mathrm{n}=13)$ & $50 \pm 3$ & $21 \pm 4$ & $57 \pm 9$ \\
\hline & Average $(n=45)$ & $51 \pm 4$ & $22 \pm 3$ & $57 \pm 7$ \\
\hline \multirow{5}{*}{ UASB } & $I(n=8)$ & $45 \pm 2$ & $40 \pm 2$ & $10 \pm 4$ \\
\hline & II $(n=12)$ & $51 \pm 3$ & $45 \pm 3$ & $12 \pm 4$ \\
\hline & III $(n=12)$ & $55 \pm 2$ & $47 \pm 6$ & $16 \pm 9$ \\
\hline & IV $(n=13)$ & $50 \pm 3$ & $36 \pm 3$ & $26 \pm 7$ \\
\hline & Average $(n=45)$ & $51 \pm 4$ & $42 \pm 6$ & $17 \pm 9$ \\
\hline
\end{tabular}


Mendoza, L. et al.

Table 5. Installation costs (in USD) of solar flat-plate collector in the pilot and full-scale GCC reactors (EEQ, 2007).

\begin{tabular}{|c|c|c|}
\hline Item & Pilot reactor $\left(10 \mathrm{~m}^{3}\right)$ & Industrial reactor $\left(100 \mathrm{~m}^{3}\right)$ \\
\hline Collectors array & 1,620 & 15,840 \\
\hline $\begin{array}{l}\text { Collectors supporting } \\
\text { assemblage }\end{array}$ & 340 & 2,500 \\
\hline $\begin{array}{l}\text { Installation accessories (storage } \\
\text { tank, ducts, pipelines) }\end{array}$ & 790 & 6,500 \\
\hline Stainless steel insulating jacket & 270 & 1,500 \\
\hline Manpower & $720^{a}$ & $2,400^{\mathrm{a}}$ \\
\hline Total costs & 3,740 & 28,740 \\
\hline
\end{tabular}

${ }^{a}$ Only for technicians, since the assistants are supposed to be provided by the municipality. 
Technical and economic feasibility of gradual concentric chambers reactor for sewage treatment in developing countries

Table 6. Estimated costs (in USD) for the construction, operation and maintenance of the pilot and industrial GCC reactors.

\begin{tabular}{|c|c|c|c|c|}
\hline & \multicolumn{2}{|c|}{ Pilot reactor $\left(10 \mathrm{~m}^{3}\right)$} & \multicolumn{2}{|c|}{ Industrial reactor $\left(100 \mathrm{~m}^{3}\right)$} \\
\hline & Option 1 & Option 2 & Option 1 & Option 2 \\
\hline \multicolumn{5}{|l|}{ Construction } \\
\hline Anaerobic compartment & 130 & 1,800 & 1,925 & 10,300 \\
\hline Headspace compartment & 185 & 2,500 & 2,900 & 21,600 \\
\hline Aerobic compartment ${ }^{a}$ & 700 & 700 & 2,900 & 2,900 \\
\hline Feeding pump & 69 & 69 & 210 & 210 \\
\hline Water recirculation pump & 69 & 69 & 210 & 210 \\
\hline Accessories (5\%) & 58 & 257 & 407 & 1,761 \\
\hline Subtotal & 1,211 & 5,395 & 8,552 & 36,981 \\
\hline Subtotal (per year) ${ }^{b}$ & 61 & 270 & 428 & 1,849 \\
\hline Solar panels installation & 3,740 & 3,740 & 28,740 & 28,740 \\
\hline Total & 4,951 & 9,135 & 37,292 & 65,721 \\
\hline Total (per year) ${ }^{b}$ & 248 & 457 & 1,865 & 3,286 \\
\hline \multicolumn{5}{|c|}{ Operational and maintenance costs (per year) } \\
\hline Energy for pumps ${ }^{c}$ & 580 & 580 & 988 & 988 \\
\hline Salaries & 176 & 176 & 352 & 352 \\
\hline $\begin{array}{l}\text { Electricity to cover } 20 \% \text { of anaerobic } \\
\text { compartment heating }\end{array}$ & 179 & 179 & 1,786 & 1,786 \\
\hline Subtotal & 935 & 935 & 3,126 & 3,126 \\
\hline $\begin{array}{l}\text { Electricity to cover } 80 \% \text { of anaerobic } \\
\text { compartment heating (per year) }\end{array}$ & 715 & 715 & 7,146 & 7,146 \\
\hline Total (per year) & 1,650 & 1,650 & 10,272 & 10,272 \\
\hline \multicolumn{5}{|l|}{ Total costs (per year) } \\
\hline Using solar collectors & 1,183 & 1,392 & 4,991 & 6,412 \\
\hline Using electricity & 1,711 & 1,920 & 10,700 & 12,121 \\
\hline
\end{tabular}

Option 1: Polyethylene vessels with capacity of 1, 2.5, 10 and $15 \mathrm{~m}^{3}$. Plastigama. National Industry, Ecuador. Option 2: Stainless steel (4 mm); manpower included.

${ }^{\mathrm{a}}$ Concrete (Ecuador, local construction prices of 2007, $130 \mathrm{USD} / \mathrm{kg}$ concrete).

${ }^{\mathrm{b}}$ Considering an operational lifetime of 20 years for reactors and collectors.

${ }^{c} 0.5$ and $0.85 \mathrm{HP}$ for the pilot and industrial reactor, respectively. 
Table 7. Yearly costs of GCC reactor per inhabitant equivalent (in USD I.E. ${ }^{-1} \mathrm{y}^{-1}$ ) and per $\mathrm{m}^{3}$ of wastewater treated (USD $\mathrm{m}^{-3}$ wastewater). See Table 6 for option 1 and option 2 characteristics.

\begin{tabular}{|c|c|c|c|c|}
\hline & \multicolumn{2}{|c|}{ Pilot reactor $\left(10 \mathrm{~m}^{3}\right)$} & \multicolumn{2}{|c|}{ Industrial reactor $\left(100 \mathrm{~m}^{3}\right)$} \\
\hline & Option 1 & Option 2 & Option 1 & Option 2 \\
\hline \multicolumn{5}{|c|}{ Investment costs (USD I.E. ${ }^{-1} y^{-1}$ ) } \\
\hline With solar collectors & 3.9 & 7.3 & 3.0 & 5.3 \\
\hline Without solar collectors & 1.0 & 4.3 & 0.7 & 3.0 \\
\hline \multicolumn{5}{|c|}{ Operational and maintenance costs (USD I.E. ${ }^{-1} y^{-1}$ ) } \\
\hline With solar collectors & 14.8 & 14.8 & 5.0 & 5.0 \\
\hline Without solar collectors & 26.2 & 26.2 & 16.4 & 16.4 \\
\hline \multicolumn{5}{|c|}{ Total costs (USD I.E. ${ }^{-1} \mathbf{y}^{-1}$ ) } \\
\hline With solar collectors & 18.7 & 22.1 & 8.0 & 10.3 \\
\hline Without solar collectors & 27.2 & 30.5 & 17.1 & 19.4 \\
\hline \multicolumn{5}{|c|}{ Total costs (USD $\mathrm{m}^{-3}$ wastewater) } \\
\hline With solar collectors & 0.6 & 0.8 & 0.3 & 0.3 \\
\hline Without solar collectors & 0.9 & 1.0 & 0.6 & 0.7 \\
\hline
\end{tabular}


Technical and economic feasibility of gradual concentric chambers reactor for sewage treatment in developing countries

Table 8. Costs of wastewater treatment technologies applied in Latin America.

\begin{tabular}{|c|c|c|c|}
\hline Treatment technology & $\begin{array}{l}\text { Construction } \\
\left.\text { (USD capita }^{-1}\right)\end{array}$ & $\begin{array}{c}\text { O\&M } \\
(\text { USD capita } \\
\left.\text { (U) } y^{-1}\right)\end{array}$ & Reference \\
\hline \multicolumn{4}{|l|}{$\mathrm{GCC}^{\mathrm{b}}$} \\
\hline With solar collectors & 60.0 & 5.0 & This study \\
\hline Without solar collectors & 14.0 & 16.4 & This study \\
\hline $\mathrm{PS}+\mathrm{AS}$ & 84.0 & 5.2 & Sandino, 2007 \\
\hline CEPT + AS & 79.0 & 5.7 & Sandino, 2007 \\
\hline CEPT & 46.0 & 4.4 & Sandino, 2007 \\
\hline UASB & 17.0 & 2.0 & $\begin{array}{c}\text { Schellinkhout and Collazos, } \\
1992\end{array}$ \\
\hline Constructed wetlands & 16.0 & 0.6 & Arias, 2006 \\
\hline SBR & 21.0 & 2.6 & Arias, 2006 \\
\hline Stabilization pond & 12.6 & 0.6 & Arias, 2006 \\
\hline
\end{tabular}

${ }^{a}$ O\&M: Operational and Maintenance costs. ${ }^{b}$ Option 1 (polyethylene vessels) of industrial scale reactor $\left(100 \mathrm{~m}^{3}\right)$ has been considered for comparison.

GCC: Gradual Concentric Chambers reactor; PS: Primary sedimentation; AS: Activated sludge; CEPT: Chemical Enhanced Primary Treatment; UASB: Upflow Anaerobic Sludge Bed reactor; SBR: Sequential Batch Reactor. 